Gut, 1973, 14, 529-534

\title{
The isolation, partial characterization, and subfractionation of human intestinal brush borders
}

\author{
S. E. HOUGHTON AND C. F. MCCARTHY
}

From the Department of Gastroenterology, Regional Hospital, and University College, Galway, Ireland

SUMMARY Brush borders were prepared from small intestinal specimens obtained from 20 patients who underwent abdominal surgery. Some enzyme constituents of the brush borders and fractions obtained from them by papain digestion are described.

The brush border is an important and interesting feature of intestinal epithelial cells since it constitutes a barrier between the cell and the lumen of the intestine. Miller and Crane (1961a) were the first to show that brush borders can be isolated as intact entities. These authors also demonstrated that brush borders isolated from hamster small intestine contained considerable amounts of the disaccharidases, invertase and maltase (Miller and Crane 1961b). Since this time brush borders have been isolated from several species and a variety of enzymes localized within them (Greenberger, 1969; Holmes, 1971). There is very little information available on human material. Welsh, Preiser, Woodley, and Crane (1972) and Cerda, Preiser, Woodley, and Crane (1971) have described the isolation of a microvillous membrane fraction from frozen human small intestine. The specific activities of sucrase, trehalase, alkaline phosphatase, and lactase of this fraction are higher than those of the original homogenate. However, there are no reports to date on the preparation or characterization of intact brush borders from fresh human small intestinal specimens.

Glycocalyx is the term first used by Bennett (1963) and includes all polysaccharide-containing structures on the external surface of cells. Our main concern has been with the enteric surface coat. The glycocalyx appears to be an integral part of the cell (Ito, 1965), being synthesized within the enterocyte and extruded to the surface of the microvilli via the Golgi apparatus (Ito, 1969; Forstner, 1969). Suggestions as to the physiological role of the enteric glycocalyx have been varied (Trier, 1969); most attention has been paid to its implied digestive function. Johnson $(1967,1969)$ isolated 'knobs' or particles about 60

Received for publication 29 March 1973.
$\AA$ in diameter by papain digestion of hamster brush borders. The 'knobs' are recovered by ultracentrifugation in a fraction of high disaccharidase activity. Oda and Seki $(1965,1966)$ have obtained similar results by papain digestion of rabbit brush border membranes. Benson, Sacktor, and Greenawalt (1971) confirmed that papain released disaccharidases from hamster brush borders but were unable to correlate this with the removal of 'knobs' from the microvilli.

Other workers (Eichholz, 1968; Forstner, 1971) have solubilized enzymes from hamster brush border membranes and rat brush borders respectively but there is no information available on the digestion of human brush borders with papain.

This paper describes the isolation and partial characterization of human brush borders obtained from segments of duodenum, jejunum, and ileum. The human brush borders are compared with those isolated from hamster small intestine. The methods of Johnson $(1967,1969)$ have been applied to the brush border preparations and a particulate fraction containing a high percentage of brush border disaccharidase activity has been isolated.

\section{Materials and Methods}

INTESTINAL SPECIMENS

Normal jejunum and duodenum were obtained at surgery from patients undergoing gastrectomy and gastroenterostomy for peptic ulceration. Ileal specimens were obtained at resections for carcinoma of the colon, ulcerative colitis, and Crohn's disease. The 20 patients (six female, 14 male) had an average age of 55 years 2 months (range 21 to 78 years). Within five minutes of removal, the intestinal segment, usually measuring between 1 and $10 \mathrm{~cm}$, was washed with ice-cold $0.9 \% \mathrm{NaCl}$. All subsequent procedures were carried out at $4^{\circ}$. 
PREPARATION OF BRUSH BORDERS

Brush borders were isolated by integration and modification of the methods of Miller and Crane (1961a) and Forstner, Sabesin, and Isselbacher (1968). The segment was blotted dry and the mucosal surface scraped off into 5 mM-EDTA, pH 7.4, (approximately $50 \mathrm{mg}$ wet weight per $\mathrm{ml}$ ) and homogenized (MSE homogenizer-maximum speed) for 20 seconds. The homogenate was passed through two layers of fine silk and centrifuged (Mistral 2L centrifuge) at $500 \mathrm{~g}$ for 10 minutes. The sediment was washed three times by resuspension and centrifugation in $5 \mathrm{ml}$ EDTA. The third sediment was then suspended in $90 \mathrm{mM}-\mathrm{NaCl}-0.8 \mathrm{mM}-\mathrm{EDTA}$ ( $50 \mathrm{mg}$ wet wt original tissue/ml), mixed thoroughly, and left to stand at room temperature for $\mathbf{3 0}$ minutes. The solution was then filtered through a glass-wool pad which was washed with a further 5-15 ml EDTA. The brush borders in the combined filtrates were sedimented at $500 \mathrm{~g}$ for $10 \mathrm{~min}$ and resuspended in a suitable volume of EDTA.

Aliquots of brush border suspensions were examined under the phase contrast microscope. Brush border pellets for examination under the electron microscope were fixed in glutaraldehyde and $\mathrm{OsO}_{4}$ and stained with uranyl acetate and lead citrate.

\section{PREPARATION OF BRUSH BORDER \\ SUBFRACTION}

Brush borders were treated with papain as described by Johnson (1967). The $3 \mathrm{ml}$ incubation volume consisted of brush borders suspended in $0.05 \mathrm{M}$ acetate buffer, pH 4.5 , containing $1.9 \mathrm{mg} / \mathrm{ml}$ $\mathrm{Na}_{2}$ EDTA, $2.6 \mathrm{mg} / \mathrm{ml}$ cysteine hydrochloride and $11.0 \mathrm{mg} / \mathrm{ml}$ papain (BDH-twice crystallized). The solution was gassed with nitrogen before the addition of the papain. After 10 minutes' incubation at $37^{\circ}$ the digestion mixture was immediately cooled in a $\mathrm{CaCl}_{2}$-ice mixture and subjected to centrifugation at $90000 \mathrm{~g}$ for $90 \mathrm{~min}$ in an MSE Superspeed 40 centrifuge. The sediment was termed precipitate 1 .

The supernatant was then recentrifuged at $140000 \mathrm{~g}$ for five hr (precipitate 2). Precipitates 1 and 2 and the supernatant were prepared for enzyme analysis by resuspension or dilution with suitable volumes of 5 mM-EDTA.

\section{CHEMICAL ANALYSES}

Protein was estimated by the method of Lowry, Rosebrough, Farr, and Randell (1951), with twice recrystallized bovine albumin as standard. DNA was determined by the method of Croft and Lubran (1965) with highly polymerized calf thymus DNA (Sigma type 1) as standard.

\section{ENZYME ASSAYS}

Sucrase and lactase were determined as described by Dahlqvist (1970). Alkaline phosphatase was measured by the rate of splitting of p-nitrophenyl phosphate (Sigma Chemical Co) (Bessey, Lowry, and Brock, 1946). The assay system contained enzyme, 30 $\mu$ moles of glycine buffer, $0.12 \mu$ moles $\mathrm{MgCl}_{2}$, $1.2 \mu$ moles zinc acetate, and $30 \mu$ moles substrate in a final volume of $0.6 \mathrm{ml}$.

\section{Results}

Brush borders isolated from both ileum and jejunum were easily recognizable under the phase contrast microscope. Electron microscopy showed that the brush borders are morphologically intact and virtually free from nuclear contamination (fig 1).

One intestinal specimen failed to yield morphologically intact brush borders. In this case the intestine was subjected to a $30-\mathrm{min}$ period of anoxia before resection.

The table shows the results for the enzyme activities and protein content of mucosal homogenates and brush border suspensions obtained from a total of

\begin{tabular}{|c|c|c|c|c|c|c|}
\hline & \multicolumn{3}{|l|}{ Human } & \multicolumn{3}{|l|}{ Hamster } \\
\hline & $\begin{array}{l}\text { Mucosal } \\
\text { Homogenate }\end{array}$ & $\begin{array}{l}\text { Brush } \\
\text { Border } \\
\text { Suspension }\end{array}$ & $\begin{array}{l}\%^{2} \\
\text { Recovery }\end{array}$ & $\begin{array}{l}\text { Mucosal } \\
\text { Homogenate }\end{array}$ & $\begin{array}{l}\text { Brush } \\
\text { Border } \\
\text { Suspension }\end{array}$ & $\begin{array}{l}\% \\
\text { Recovery }\end{array}$ \\
\hline $\begin{array}{l}\text { Sucrase IU/g protein } \\
\text { Lactase IU/g protein } \\
\text { Alkaline phosphatase IU/g protein } \\
\text { Protein } \mathrm{mg}\end{array}$ & $\begin{array}{r}118 \pm 37 \\
25 \pm 11 \\
117 \pm 50 \\
93 \cdot 6\end{array}$ & $\begin{array}{l}772 \pm 284 \\
96 \pm 46 \\
938 \pm 310 \\
1 \cdot 4\end{array}$ & $\begin{array}{r}23 \cdot 9 \\
22 \cdot 2 \\
20 \cdot 2 \\
1 \cdot 5\end{array}$ & $\begin{array}{l}60 \pm 34 \\
42 \pm 24 \\
172 \pm 142 \\
124 \cdot 7\end{array}$ & $\begin{array}{c}578 \pm 287 \\
283 \pm 174 \\
747 \pm 614 \\
5 \cdot 4\end{array}$ & $\begin{array}{r}30 \cdot 3 \\
20 \cdot 2 \\
25 \cdot 3 \\
4 \cdot 3\end{array}$ \\
\hline
\end{tabular}

Table Enzyme activity and DNA content of human and hamster small intestinal mucosal homogenate and brush border suspension ${ }^{1}$

1 The data listed for human material represent mean values obtained from three duodenal, 13 jejunal, and four ileal specimens. The hamster results were taken from 24 experiments. Standard deviations are included in the table.

'Percentage of initial enzyme protein and DNA content of intestinal mucosal homogenate recovered in purified brush border suspension. 


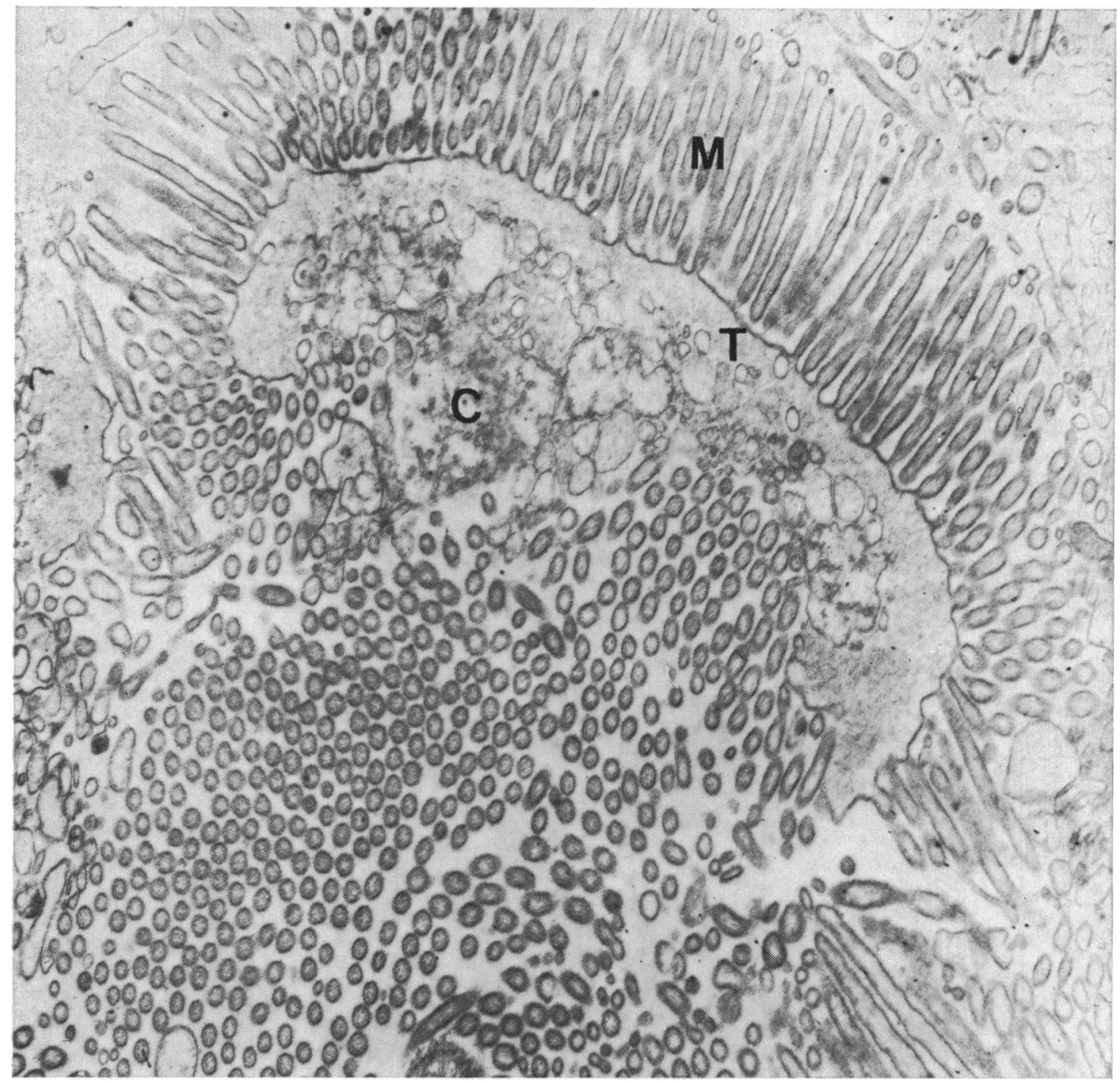

Fig 1 Sectioned pellet of human brush border preparation (magnification 14000). $M=$ microvilli. $T=$ terminal web. $C=$ attached cytoplasm.

20 intestinal specimens (three duodenal, 13 jejunal, and four ileal). The specific activity of sucrase in the isolated brush borders is 6.5 times higher than in the original mucosal homogenate. Similarly, the activities of lactase and alkaline phosphatase are increased by factors 4 and 8 respectively. There was no significant difference in enzyme activity between duodenal, jejunal, and ileal brush borders.

Also shown in the table are the results from a total of 24 hamster experiments for comparison. Again it can be seen that the specific activities of the enzymes increase as the brush borders are isolated. The percentages of initial enzyme, protein, and DNA content of the intestinal mucosal homogenate recovered in the final purified brush border suspension are indicated. Between 20 and $30 \%$ of the initial mucosal enzyme activity was found in the brush borders in each case. However, it can be seen that the purified preparation contained only a small fraction of the nuclear contamination. Preliminary experiments in which the brush border suspension was not filtered through glass-wool 
yielded much higher enzyme recovery figures (about $50-55 \%$ ) but with a correspondingly high DNA content (about 5-8\%). It was decided, therefore, since the subsequent papain experiments demanded a high degree of purity, to include the extra purification step in our preparative procedure at the expense of the enzyme recovery figures.

The percentage of the total enzyme activity recovered in each subfraction and after papain treatment of human brush borders is shown in figs 2,3 , and 4 compared with the results obtained when brush borders are incubated under the same conditions without papain. In the case of invertase a very high percentage of the activity was recovered in the particulate fraction, precipitate 2; similar results can be seen with lactase. Alkaline phosphatase, however, remained in the supernatant fraction.

Preliminary experiments showed that papain $(11.0 \mathrm{mg} / \mathrm{ml})$ does not affect the activity of the three enzymes under investigation.

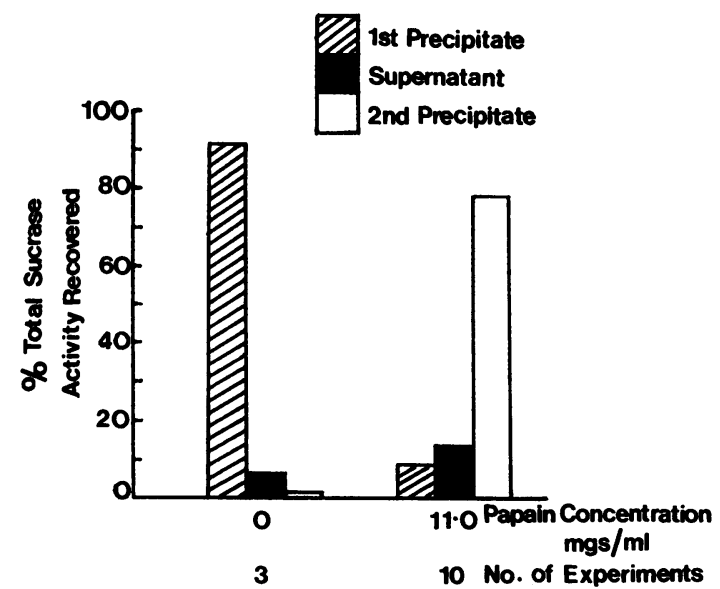

Fig 2 The percentage of sucrase recovered in each human brush border subfraction. Brush borders were subfractionated by ultracentrifugation after incubation for 10 minutes with and without papain.

\section{Discussion}

The evidence for modern concepts of intestinal absorption and enzyme localization is based to a large extent on data from various non-human mammalian species. The prime purpose of the work described in this paper has been to provide an experimental basis for the extrapolation of these

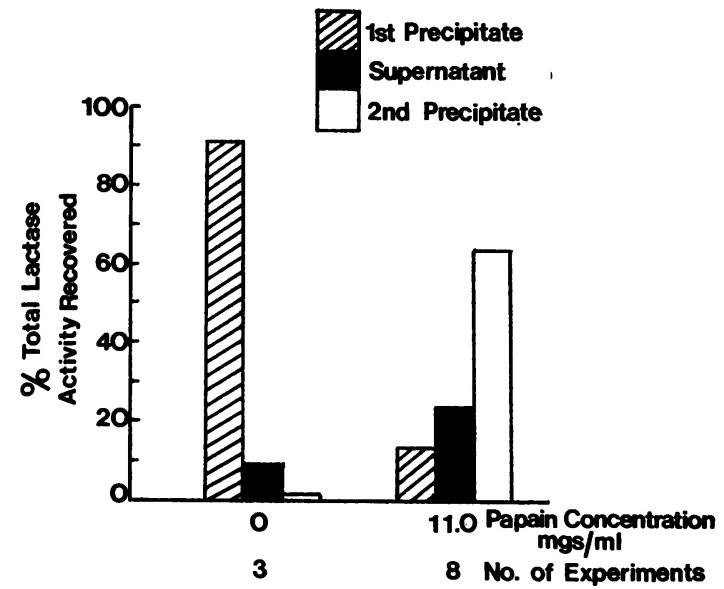

Fig 3 The percentage of lactase recovered in each human brush border subfraction. Brush borders were subfractionated by ultracentrifugation after incubation for 10 minutes with and without papain.

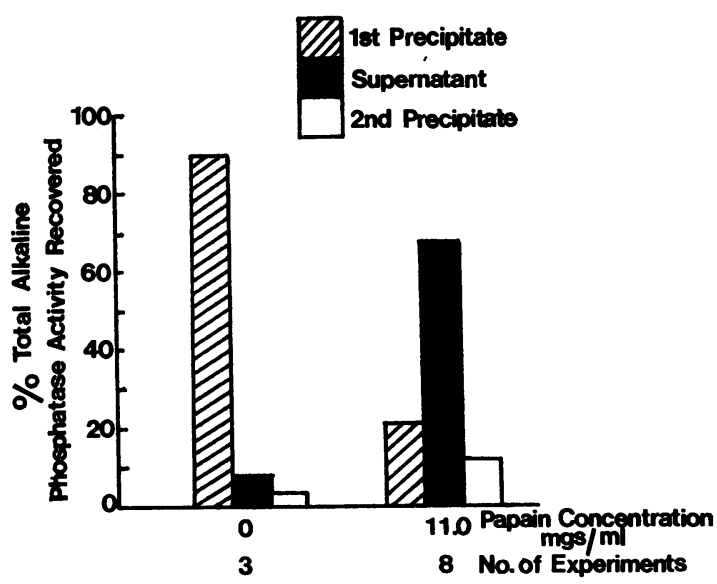

Fig 4 The percentage of alkaline phosphatase recovered in each brush border subfraction. Brush borders were subfractionated by ultracentrifugation after incubation for 10 minutes with and without papain.

concepts to include human systems. There are numerous disadvantages to be encountered when working with human material based mainly on the infrequent availability of fresh operation specimens. Some of the data reported, therefore, are based on a smaller number of experiments than would optimally be required.

The microscopic findings show that human 
brush borders can be isolated in as pure and undamaged a state as those of other species. Biochemically the purification factor from mucosal homogenate to pure brush border suspension, using invertase as a marker, supports this. The degree of purity of the suspension is also emphasized by the elimination of a high percentage of the contaminating DNA.

All three of the enzymes measured appear to be localized in the microvilli of the human intestine, as they are in other species. Disaccharidase activities have been reported as distributed uniformly throughout the small intestinal mucosa except in the duodenum and terminal ileum (Auricchio, Rubino, and Murset, 1965). Our brush border results are in agreement insofar as no significant differences between the enzyme activities of jejunal and ileal brush borders were found. There was also no difference detected between the duodenum and the rest of the intestine. It must be remembered, however, that the numbers of specimens, especially duodenal, were somewhat limited.

Further confirmation that human brush borders are similar to those of other species comes from the demonstration that their disaccharidase activity can be isolated in a particulate fraction.

In our experiments alkaline phosphatase, although solubilized from the microvillous membrane, was not sedimented by ultracentrifugation. This is in contrast to Oda and Seki (1966) who, using rabbit microvillous membranes, reported that alkaline phosphatase is not solubilized by papain treatment. Eichholz (1968) also disagrees with these workers and suggests that the discrepancy may indicate a species difference. It seems likely that Eichholz's alternative suggestion that the difference is attributable to differences in experimental technique is correct. We have found that, when comparing the behaviour of hamster and human brush borders under identical experimental conditions, the distributions of alkaline phosphatase are the same.

Johnson (1969) and Oda and Seki (1966) have visualized the removal of the enzyme-containing particles ('knobs') electronmicrographically using a negative staining method. Repeated attempts to use this technique on our work were unsuccessful. Under positive staining conditions the glycocalyx is visualized as a filamentous surface layer or 'fuzz'. This was clearly visible on brush border sections of both human and hamster material. It has yet to be shown whether or not the surface filaments and knobs are identical although Forstner's (1971) results are compatible with this suggestion.

Brush borders have already been shown to have localized binding properties (Holmes, 1971). For example, ileal brush borders bind vitamin- $\mathbf{B}_{12}$ intrinsic factor (Donaldson, MacKenzie, and Trier, 1967) and proximal brush borders bind ferrous iron (Greenberger, Balcerzak, and Ackerman, 1969). It would be particularly interesting to test the localized binding properties of the particulate fraction in this respect.

The authors wish to thank the surgeons of the Regional Hospital, Galway, for providing the operation specimens, members of the Biochemistry Department, University College, Galway, for helpful discussion and the Medical Research Council of Ireland for financial support.

\section{References}

Auricchio, S., Rubino, A., and Murset, G. (1965). Intestinal glycosidase activities in the human embryo, fetus and newborn. Pediatrics, 35, 944-954.

Bennett, H. S. (1963). Morphological aspects of extracellular polysaccharides. J. Histochem. Cytochem., 11, 14-23.

Benson, R. L., Sacktor, B., and Greenawalt, J. W. (1971). Studies on the ultrastructural localization of intestinal disaccharidases. J. Cell Biol., 48, 711-716.

Bessey, O. A., Lowry, O. H., and Brock, M. J. (1946). A method for the rapid determination of alkaline phosphatase with $5 \mathrm{cmm}$ of serum. J. biol. Chem., 164, 321-329.

Cerda, J. J., Preiser, H., Woodley, J. F., and Crane, R. K. (1971). Preparation of human microvillus membranes from frozen per-oral jejunal biopsies from normal subjects and from patients with malabsorption syndromes. Clin. Res., 19, 655 .

Croft, D. N., and Lubran, M. (1965). The estimation of deoxyribonucleic acid in the presence of sialic acid: application to analysis of human gastric washings. Biochem. J., 95, 612-620.

Dahlqvist, A. (1970). Assay of intestinal disaccharidases. Enzym. biol. clin., 11, 52-66.

Donaldson, R. M., Jr., MacKenzie, I. L., and Trier, J. S. (1967). Intrinsic factor-mediated attachment of vitamin $\mathrm{B}_{1}$, to brush borders and microvillous membranes of hamster intestine. $J$. clin. Invest., 46, 1215-1228.

Eichholz, A. (1968). Studies on the organization of the brush border in intestinal epithelial cells. V. Subfractionation of enzymatic activities of the microvillus membrane. Biochem. biophys. Acta (Amst.), 163, 101-107.

Forstner, G. G. (1969). Surface sugar in the intestine. Amer. J. med. Sci., 258, 172-180.

Forstner, G. G. (1971). Release of intestinal surface-membrane glycoproteins associated with enzyme activity by brief digestion with papain. Biochem. J., 121, 781-789.

Forstner, G. G., Sabesin, S. M., and Isselbacher, K. J. (1968). Rat intestinal microvillus membranes. Biochem. J., 106, 381-390.

Greenberger, N. J. (1969). The intestinal brush border as a digestive and absorptive surface. Amer. J. med. Sci., 258, 144-149.

Greenberger, N. J., Balcerzak, S. P., and Ackerman, G. A. (1969). Iron uptake by isolated intestinal brush borders. J. Lab. clin. Med., 73, 711-721.

Holmes, R. (1971). The intestinal brush border. Gut, 12, 668-677.

Ito, S. (1965). The Enteric surface coat on cat intestinal microvilli. $J$. Cell Biol., 27, 475-491.

Ito, S. (1969). Structure and function of the glycocalyx. Fed. Proc., 28, 12-25.

Johnson, C. F. (1967). Disaccharidase: localization in hamster intestine brush borders. Science, 155, 1670-1672.

Johnson, C. F. (1969). Hamster intestinal brush border surface particles and their function. Fed. Proc., 28, 26-29.

Lowry, O. H., Rosebrough, N. J., Farr, A. L., and Randell, R. J. (1951). Protein measurement with the folin phenol reagent. J. biol. Chem., 193, 265-275.

Miller, D., and Crane, R. K. (1961a). A procedure for the isolation of the epithelial brush border membrane of hamster small intestine. Analyt. Biochem., 2, 284-286.

Miller, D., and Crane, R. K. (1961b). The digestive function of the 
epithelium of the small intestine. II. Localization of disaccharide hydrolysis in the isolated brush border portion of intestinal epithelial cells. Biochim. biophys. Acta (Amst.), 52, 293-298.

Oda, T., and Seki, S. (1965). Molecular structure and biochemical function of the microvilli membrane of intestinal epithelial cells with special emphasis on the elementary particles. $J$. Electron Micr., 14, 210-217.

Oda, T., and Seki, S. (1966). Molecular basis of structure and function of the plasma membrane of the microvilli of intestinal epithelial cells. In Proceedings of the Sixth International Congress for Electron Microscopy, Kyoto, pp. 387-388.

Trier, J. S. (1969). The surface coat of gastro-intestinal epithelial cells. Gastroenterology, 56, 618-622.

Welsh, J. D., Preiser, H., Woodley, J. F., and Crane, R. K. (1972). An enriched microvillus membrane preparation from frozen specimens of human small intestine. Gastroenterology, 62, 572-582. 